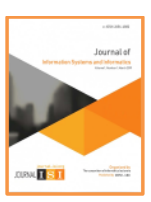

Vol. 3, No. 1, March 2021 e-ISSN: 2656-4882 p-ISSN: 2656-5935

http://journal-isi.org/index.php/isi

Published By DRPM-UBD

\title{
Implementasi Waterfall Model Dalam Pengembangan Sistem Informasi Eksekutif Penduduk
}

\author{
Ekkal Prasetyo ${ }^{1}$, Ade Putra $* 2$ \\ ${ }^{1}$ Program Studi Teknik Informatika, Politeknik Sekayu \\ ${ }^{2}$ Fakultas Vokasi, Universitas Bina Darma, Palembang \\ e-mail: 1excal.polsky@gmail.com, *2 ade.putra@binadarma.ac.id
}

\begin{abstract}
Abstrak
Kebutuhan informasi menjadi sangat penting terutam dalam proses pengambilan keputusan. Salah satu cara yang dapat digunakanyaitu menggunakan teknologi informasi dan komunikasi seperti sistem informasi. sistem informasi sendiri memiliki berbagai macam diantaranya yaitu sistem informasi eksekutif yang banyak digunakan untuk menyajikan informasi kepada pihak eksekutif dalam mengambil keputusan atau kebijakan. Seperti halnya yang terjadi diberbagai kecamatan saat ini kebutuhan informasi penduduk menjadi sangat penting mengingat dibutuhkan dalam pengambilan kebijakan bagi pemerintah. untuk itu di dalam penelitian ini dibuat sebuah sistem informasi eksekutif penduduk guna membantu memetakan keadaan penduduk berdasarkan data kependudukan itu sendiri. untuk menghasilkan sistem informasi eksekutif sesuai dengan kebutuhan eksekutif maka proess pengembangan digunakan waterfall model dengan lima tahapan pengembangan communication, planning, modeling, construction, dan deployment. Hasil dari pengembangan berupa sistem informasi eksekutif yang dapat memberikan informasi secara visual kepada pihak terkait. Sistem informasi juga berjalan dengan baik yang dibutkikan dari hasil pengujian yang dilakukan.
\end{abstract}

Kata kunci- Waterfall model, pengembangan, sistem informasi, penduduk

\section{PENDAHULUAN}

Teknologi informasi dan komunikasi (TIK) saat ini hampir menyentuh hampir di semua sendi kehidupan. Kondisi tersebut dapat dilihat dari berbagai aspek telah menggunakan TIK itu sendiri. pada dunia pendidikan penggunaan TIK dapat dilihat adanya sistem informasi akademik, e-learning, sedangkan di dunia industri dapat dilihat adanya berbagai macam e-commerce dan pada dunia pemerintahan dapat dilihat dari bebagai aplikasi layanan maupun aplikasi smarti city. Implementasi dati TIK sendiri dapat dilihat banyaknya sistem informasi yang digunakan saat ini. 
Hampir semua instansi saat ini menggunakan sistem informasi dalam menunjang kegiatan atau proses bisnis sebuah instansi. Sebagaimana diketahui bahwa sistem informasi merupakan elemen yang saling terkait untuk menyajikan informasi dari hasil pengolahan data yang dapat digunakan oleh penggunanya [1].

Sistem informasi dilihat dari jenisnya memiliki berbagai macam jenis, yaitu "transaction processing systems (TPS). office automation systems (OAS), knowledge work systems (KWS), management information system (MIS), decision support systems (DSS), expert system, group decision support systems (GDSS), computer support collaborative cork Systems (CSCW) dan executive support systems (ESS)" [2]. Salah satu sistem informasi yang dapat digunakan untuk melihat informasi dalam mengambil kebijakan adalah executive support systems atau sistem informasi eksekutif.

Sistem informasi eksekutif telah dimanfaatkan diberbagai bidang diantaranya adalah dalam bidang pemasaran. Dimana sistem informasi eksekutif digunakan untuk melihat bagaimana sebaran pembeli [3] dan juga informasi detail dari penjualan [4]. Selain dalam bidang pemasaran impelementasi sistem informasi eksekutif juga dilakukan dalam bidang Pendidikan, dimana dapat dilihat sistem informasi eksekutif digunakan untuk melihat informasi mahasiswa yang digunakan bagi bagian kemahasiswaan [5]. Dalam bidang Pendidikan juga digunakan untuk pemetaan data dosen itu sendiri [6].

Melihat luasnya pemanfaatan sistem informasi eksekutif maka kondisi tersebut sangat memungkinkan untuk digunakan dalam hal kependudukan. Karena sebagaimana diketahui informasi kependudukan menjadi sangat penting terutama bagi pihak terkait seperti pihak kecamatan. Dengan adanya informasi yang mudah untuk diakses maka dalam mengambil tindakan atau keputusan akan menjadi lebih mudah untuk dilakukan.

Agar mendapatkan sistem informasi eksekutif sesuai dengan kebutuhan pihak terkait maka dalam proses pengembangan digunakan metode waterfall sebagai alur proses pengembangan. metode waterfall merupakan metode pengembangan terstruktur dengan proses pengembangan yang terdiri dari communication, planning, modeling, construction, dan deployment [7]. Untuk itu dalam penelitian ini dilakukan implementasi waterfall model dalam pengembangan sistem informasi eksekutif penduduk dengan harapan informasi yang disajikan dapat digunakan bagi pihak terkait dalam mengambil tindakan atau keputusan.

\section{METODOLOGI PENELITIAN}

Untuk menyeleisaikan proses penelitian maka dapat dijelaskan metode yang digunakan sebagai langkah-langkah peneleitian tersebut sebagai berikut: 


\subsection{Metode Penelitian}

Dalam melakukan peneltian implementasi waterfall model dalam pengembangan sistem informasi eksekutif penduduk metode penelitian yang digunakan adalah metode deskriptif. Pada berbagai kajian menjelaskan bahwa metode deskriptif merupakan metode yang mampu menjelaskan fakta dan fenomena dari sebuah objek penelitian yang dilihat dari sudut pandang peneliti [8]. Dengan kata lain metode deskriptif merupakan metode yang dapat digunakan untuk memaparkan keadaan objek penelitian berdasarkan fakta dan kejadi yang alami oleh peneliti dan dijelaskan sesuai perspektif peneliti [9].

\subsection{Metode Pengembangan}

Untuk menghasilkan sistem informasi eksekutif yang sesuai dengan kebtuhan dalam menyajikan informasi kependudukan, maka dalam proses pengembangan diguakan sebuah metode pengembangan. Metode pengembangan yang digunakan yaitu metode pengembangan kasik yaitu waterfall model. Waterfall model ini telah mengalami beberapa perkembangan dalam langkah-langkah pengembangan. Tahapan metode waterfall terdapat dua jenis yaitu pertama: requirement analysis, design, implementation, testing, dan maintenance [14]. Kedua yaitu: communication, planning, modeling, construction, dan deployment [15]. Untuk itu dalam proses pengembangan sistem informasi eksekutif penduduk ini digunakan proses pengembangan cara kedua. Proses pengembangan dengan cara kedua ini seperti yang diperlihatkan pada Gambar 1.

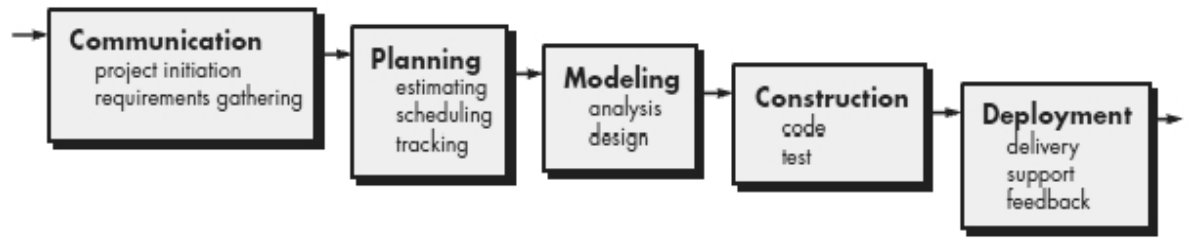

Gambar 1. Waterfall Model

Sesuai dengan proses pengembangan sistem informasi eksekutif seperti yang diperlihatkan pada Gambar 1 maka dapat dijelaskan proses untuk setiap tahapan sebagai berikut:

a. Communication, aktivitas dan pekerjaan yang dilakukan pada tahapan communication yaitu analisis kebutuhan awal sesuai dengan project initiation. Pada tahapan ini terdapat aktivitas pengumpulan data yang akan digunakan dalam proses pengembangan sistem informasi executive. Analisis dan pengumpulan data tersebut meliputi data monografi, Pendidikan, jenis Pendidikan, kecamatan, pekerjaan, jenis pekerjaan, desa, penduduk, 
kependudukan, tenaga medis, kendaraan dan lapangan olah raga. Selain itu juga dilakukan pengumpulan informasi berkaitan kebutuhan informasi dalam dashboard informasi yang akan ditampilkan.

b. Planning, aktivitas dan pekerjaan yang dilakukan pada tahapan planning yaitu membuat perencanaan dalam proses pengembangan sistem infomrasi eksekutif. Perancangan tersebut meliputi tiga aspek yaitu estimating, scheduling dan tracking. Dalam proses ini dilakukan pembuatan jadwal pengerjaan sistem informasi yang dilakukan selama lebih kurang tiga bulan. Sedangkan tracking dilakukan untuk melihat perkembangan proses pengembangan sistem informasi seperti review perkembangan setiap seminggu sekali agar dikerjakan tepat waktu.

c. Modeling, aktivitas dan pekerjaan yang dilakukan pada tahapan modeling yaitu membuat sebuah model analisis dan perancangan antarmuka dari sistem infomrasi eksekutif yang akan dihasilkan. Namun dalan penelitian ini hanya akan dibuat dari hasil model anaslsis menggunakan unified modeling language (UML). Pemodalan sistem informasi adalah proses penentuan kebutuhan yang digambarkan dalam bentuk unified modeling language (UML). UML sendiri merupakan diagram Degnan kemampuan untuk menggambarkan cetak biru dari sistem informasi yang akan dihasilkan. Dengan diagram UML juga dapat dilihat bagaimana sistem informasi akan dibentuk [10]. Dalam penelitian ini digunakan dua diagram UML yaitu use case diagram dan class diagram. Use case diagram digunakan untuk menggambarkan bagaimana tingkah laku dari sistem informasi yang berkaitan dengan aktor [11]. Gambar 2 merupakan use case diagram dari sistem informasi eksekutif.

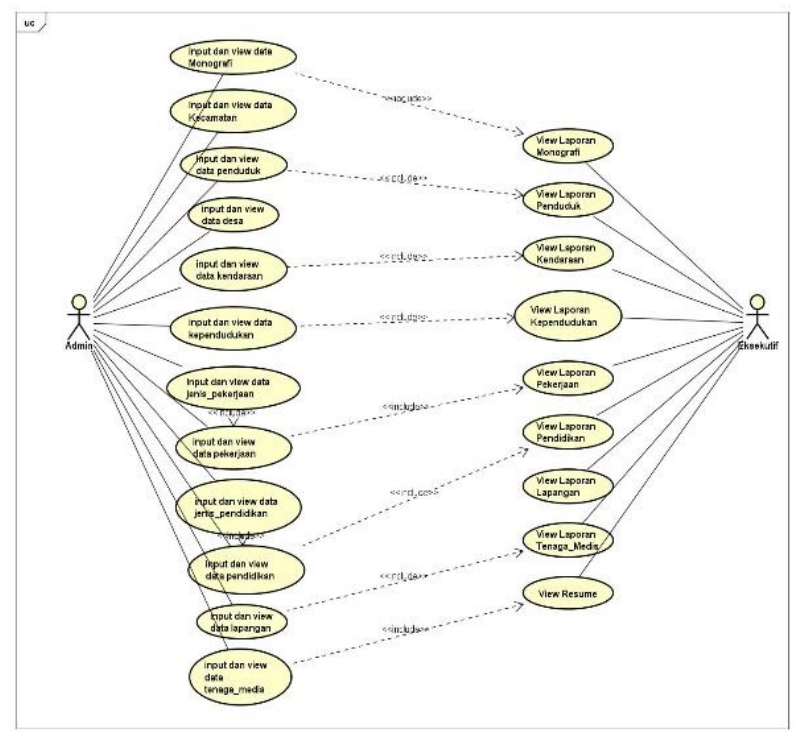

Gambar 2. Use Case Diagram 
Vol. 3, No. 1, March 2021

p-ISSN: 2656-5935 http://journal-isi.org/index.php/isi

e-ISSN: 2656-4882

Sesuai dengan Gambar 2 maka dapat diketahui dalam sistem informasi yang dihasilkan nanti memiliki dua aktor yaitu admin dan pihak eksekutif. Pihak admin adalah pihak melakukan pengelohan data yang terdiri dari data monografi, kecamatan, penduduk, desa, kendaraan, kependudukan, jenis pekerjaan, pekerjaan, jenis pendidikan, lapangan, dan tenaga medis. Sedangkan aktor eksekutif adalah pihak yang melihat informasi dari hasil pengeolahan data yang dilakukan dalam sistem informasi eksekutif.

Selanjutnya adalah class diagram, class diagram merupakan diagram yang digunakan untuk membentuk struktur dari sistem informasi eksekutif penduduk [12]. Terdapat dua belas class sebagai pembentuk sistem informasi yaitu monografi, Pendidikan, jenis Pendidikan, kecamatan, pekerjaan, jenis pekerjaan, desa, penduduk, kependudukan, tenaga medis, kendaraan dan lapangan olah raga seperti yang diperlihatkan pada Gambar 3 .

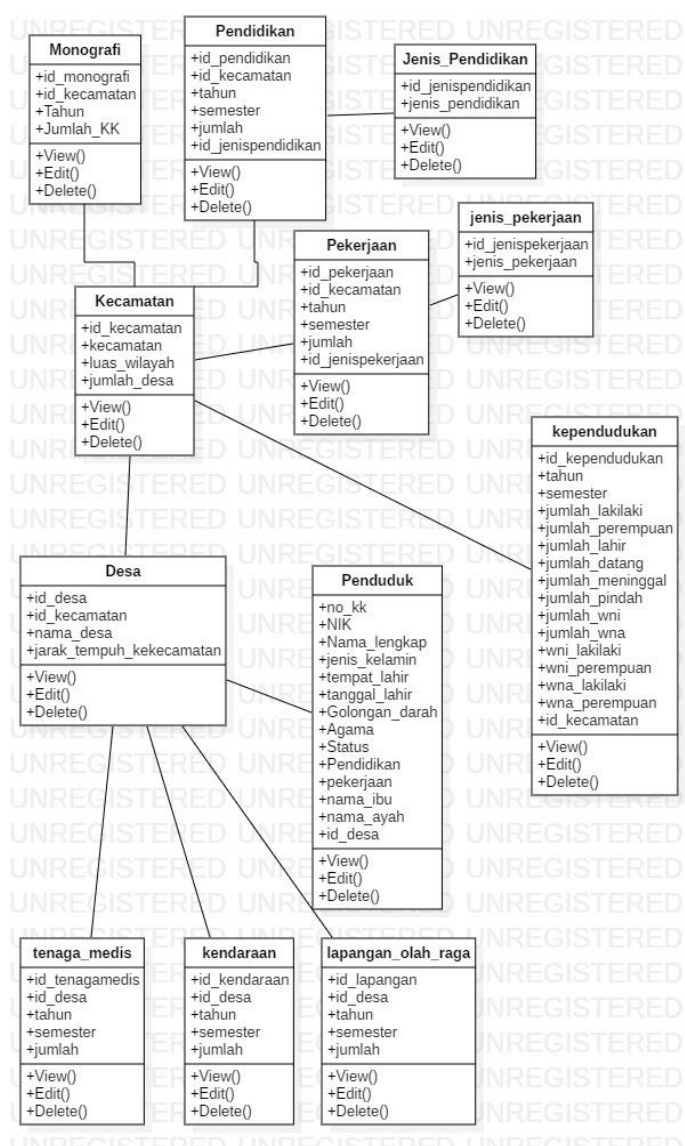

Gambar 3. Class Diagram 
d. Construction, aktivitas dan pekerjaan yang dilakukan pada construction yaitu proes penterjemahan hasil modeling kedalam bentuk coding. Dalam tahapan ini akan dihasilkan sebuah sistem informasi eksekutif penduduk bagi kecamatan.

e. Deployment, tahapan deployment merupakan proses terakhir yang dilakukan. Pada tahapan ini dilakukan pengiriman (delivery) sistem informasi eksekutif kepada pemakai.

\section{HASIL DAN PEMBAHASAN}

Sesuai dengan proses penelitian yang dilakukan yaitu mengikuti prosedur pengembangan sistem informasi eksekutif penduduk menggunakan waterfallmodel maka hasil penelitian yang didapat berupa sistem informasi eksekutif penduduk. Dimana proses pengembangan dimulai dari pengumpulan kebutuhan dan pembuatan model sistem informasi dan pengembangan sistem informasi itu sendiri. untuk itu dapat dijelaskan hasil pengembangan berbdasarka dari pemodelan kebutuhan sistem informasi sebagai berikut.

Hasil pengembangan merupakan tahapan yang dilakukan pada proses construction dari waterfall model. Dimana pada fase ini dihasilkan sistem informasi eksekutif. Gambar 4 merupakan tampilan awal dari sistem informasi eksekutif penduduk, dimana pengguna diminta untuk melakukan login untuk berinteraksi dengan sistem informasi. seperti yang diperlihatkan pada Gambar 2 bahwa pengguna yang ada pada sistem informasi ini terdiri dari admin dan pihak eksekutif dalam hal ini pihak kecamatan.

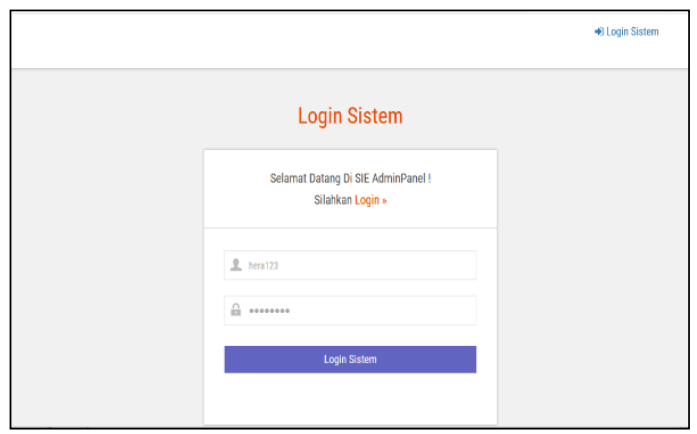

Gambar 4. Login Pengguna

Ketika pengguna admin melakukan login maka pengguna jenis ini adalah yang dapat melakukan pengolahan data yang terdiri dari monografi, Pendidikan, jenis Pendidikan, kecamatan, pekerjaan, jenis pekerjaan, desa, penduduk, kependudukan, tenaga medis, kendaraan dan lapangan olah raga. Tampilan utama pengguna admin seperti yang diperlihatkan pada Gambar 5 . 
Vol. 3, No. 1, March 2021

p-ISSN: 2656-5935 http://journal-isi.org/index.php/isi e-ISSN: 2656-4882

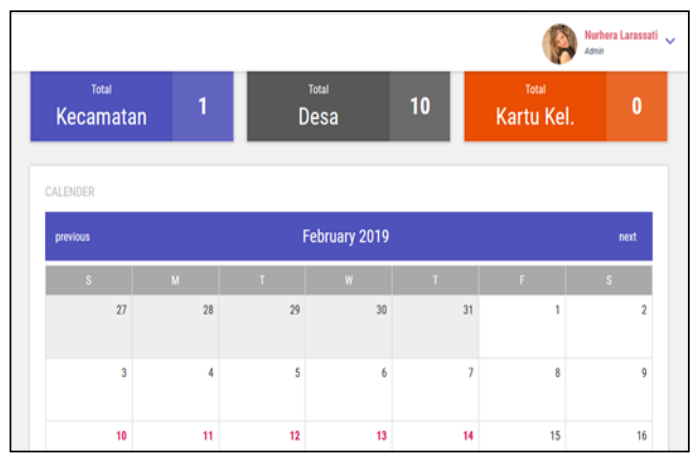

Gambar 5. Dashboard Pengguna

Dari halaman utama pengguna admin seperti yang diperlihatkan pada Gambar 5 maka admin dapat melakukan pengolahan data seperti yang telah dijelaskan sebelumnya. salah satu proses pengolahan data yang dilakukan oleh admin yaitu pengolahan data kependudukan seperti yang diperlihatkan pada Gambar 6.

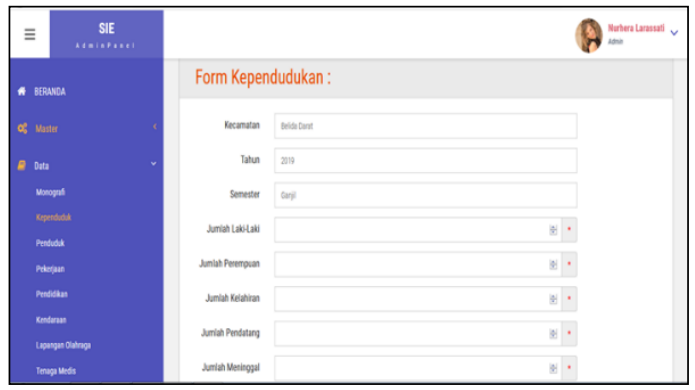

Gambar 6. Pengolahan Data

Setelah proses pengolahan data dilakukan maka selanjutnya pihak eksekutif dalam melihat data dalam bentuk laporan eksekutif. Laporan eksekutif tersebut dibuat dalam bentuk grafik untuk memudahkan dalam membaca data yang telah dimasukkan oleh admin sistem informasi eksekutif penduduk. Gambar 7 merupakan penduduk yang dilihat berdasarkan jenis kelamin.
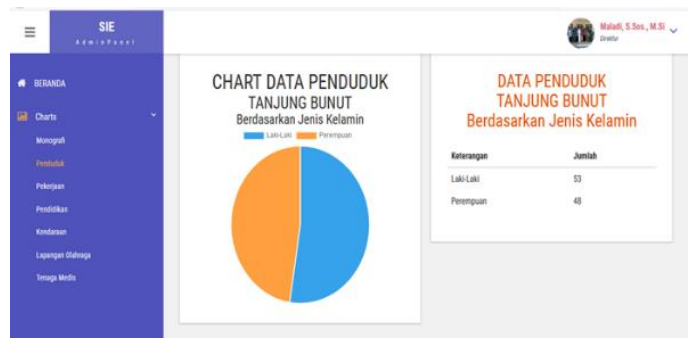

Gambar 7. Penduduk Jenis Kelamin 
Pihak eksekutif juga dapa melihat laporan peneuduk yang dilihat dari pendidikan penduduk. Dimana data pedidikan penduduk tersebut dikelompokkan mulai dari taman kanak-kanak, sekolah dasar, madrasyah, sekolah menengah pertama, sekolah memengah atas yang dilihat untuk setiap desa. Tampilan pendidikan penduduk tersebut seperti yang diperlihatkan pada Gambar 8.

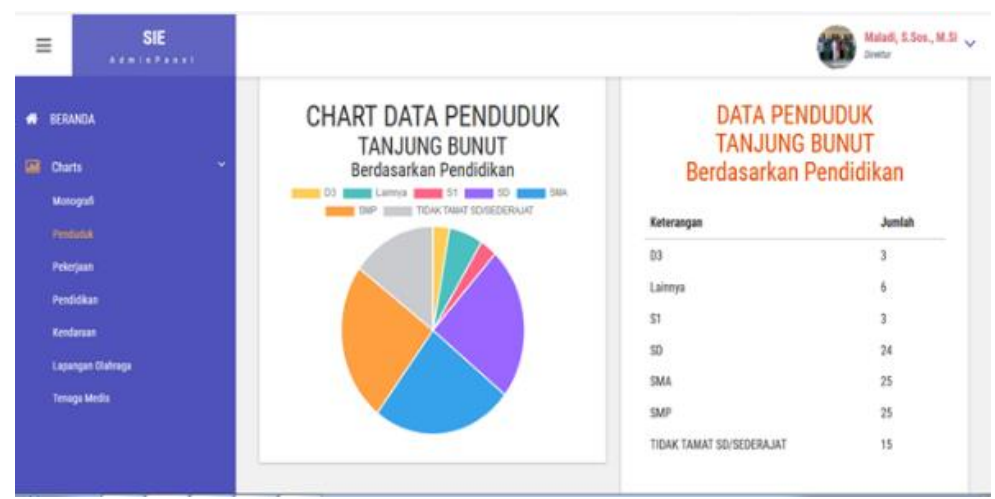

Gambar 8. Pendidikan Penduduk

Selain dapat melihat penduduk berdasarkan Pendidikan, pihak eksekutif juga dapat melihat penduduk berdasarkan usia penduduk. Dimana informasi ini seperti yang diperlihatkan pada Gambar 9.
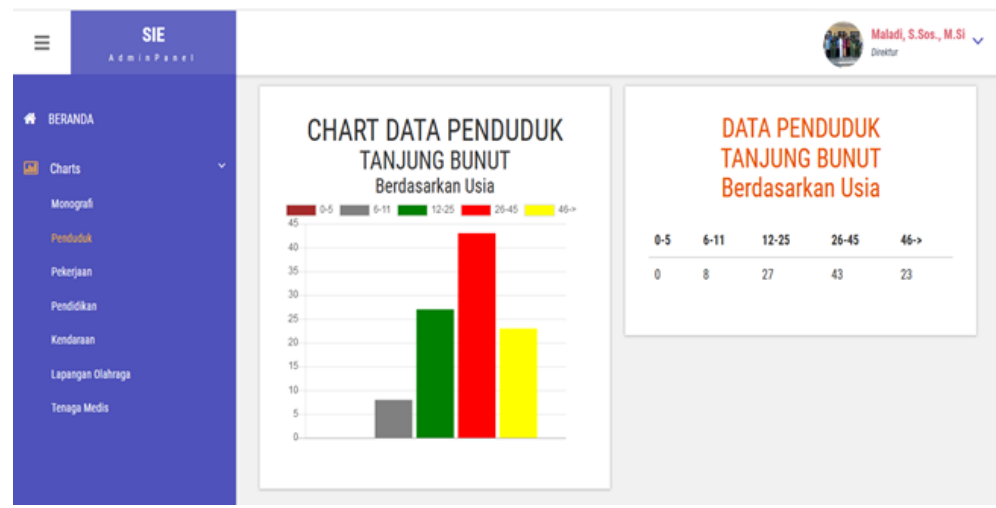

Gambar 9. Usia Penduduk

Pihak eksekutif juga dapat melihat informasi laporan penduduk yang dilihat dari jenis pekerjaan dan desa tempat tinggal penduduk. Jenis pekerjaan yang ada meliputi tidak bekerja, buruh harian, guru, karyawan, mengurus rumah tangga, pegawai negeri sipil, pelajar dan pejabat. Gambar 10 merupakan laporan eksekutif yang dilihat berdasrakan jenis pekerjaan. 
Vol. 3, No. 1, March 2021

p-ISSN: 2656-5935 http://journal-isi.org/index.php/isi e-ISSN: 2656-4882

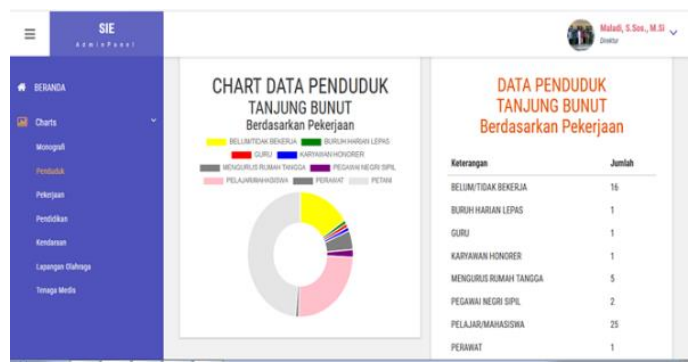

Gambar 10. Jenis Pekerjaan

Selain dari informasi yang bersifat pekendudukan terdapat juga informasi bagi eksekutif yang dapat melihat informasi fasilitas desa atau yang berkaitan denan desa seperti fasiltias desa dan tenaga medis yang terdapat disebuah desa. Gambar 11 merupakan salah satu tampilan untuk melihat infromasi dari fasiltias yang dimiliki bagi sebuah desa.

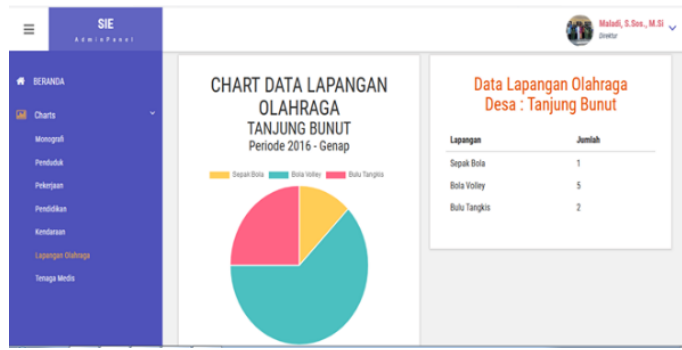

Gambar 11. Lapangan Olahraga

Setelah melakukan pengembangan sistem informasi eksekutif seperti yang telah dijelaskan sebelumnya maka selanjutnya untuk memastikan bahwa sistem informasi yang dihasilkan telah berjalan dan berfungsi sesuai dengan fungsinya maka dilakukan pengujian. Pengujian yang dilakukan menggunakan teknik black box. Pengujian dengan teknik ini untuk melihat proses masukkan dan keluaran yang dihasilkan dari sistem informasi. hasil pengujian yang dilakukan seperti yang diperlihatkan pada Tabel 1.

Tabel 1. Hasil Pengujian Sistem Informasi

\begin{tabular}{|l|l|c|}
\hline \multicolumn{1}{|c|}{ Komponen } & \multicolumn{1}{|c|}{ Bahan Uji } & Hasil Uji \\
\hline Halaman Login & Masukkan Username & Berhasil \\
\hline $\begin{array}{l}\text { Halaman Utama } \\
\text { Admin }\end{array}$ & Checklist hak akses menu & Berhasil \\
\hline \multirow{4}{*}{$\begin{array}{l}\text { Halaman Data } \\
\text { User }\end{array}$} & Tambah Data User & Berhasil \\
\cline { 2 - 3 } & Lihat Data User & Berhasil \\
\cline { 2 - 3 } & Edit Data User & Berhasil \\
\cline { 2 - 3 } & Hapus Data User & Berhasil \\
\hline
\end{tabular}


Vol. 3, No. 1, March 2021

p-ISSN: 2656-5935 http://journal-isi.org/index.php/isi e-ISSN: 2656-4882

\begin{tabular}{|c|c|c|}
\hline \multirow{4}{*}{$\begin{array}{l}\text { Halaman Data } \\
\text { desa }\end{array}$} & Tambah data desa & Berhasil \\
\hline & Lihat data desa & Berhasil \\
\hline & Delete data desa & Berhasil \\
\hline & Edit data desa & Berhasil \\
\hline \multirow{4}{*}{$\begin{array}{l}\text { Halaman Data } \\
\text { Kecamatan }\end{array}$} & Tambah data Kecamatan & Berhasil \\
\hline & Lihat data Kecamatan & Berhasil \\
\hline & Delete data Kecamatan & Berhasil \\
\hline & Edit data Kecamatan & Berhasil \\
\hline \multirow{4}{*}{$\begin{array}{l}\text { Halaman data } \\
\text { jenis pekerjaan }\end{array}$} & Tambah data jenis pekerjaan & Berhasil \\
\hline & Lihat data jenis pekerjaan & Berhasil \\
\hline & Delete data jenis pekerjaan & Berhasil \\
\hline & $\begin{array}{l}\text { Edit data jenis } \\
\text { Pekerjaan }\end{array}$ & Berhasil \\
\hline \multirow{4}{*}{$\begin{array}{l}\text { Halaman data } \\
\text { jenis pendidikan }\end{array}$} & Tambah data jenis pendidikan & Berhasil \\
\hline & Lihat data jenis pendidikan & Berhasil \\
\hline & Delete data jenis pendidikan & Berhasil \\
\hline & $\begin{array}{l}\text { Edit data jenis } \\
\text { Pendidikan }\end{array}$ & Berhasil \\
\hline \multirow{4}{*}{$\begin{array}{l}\text { Halaman data } \\
\text { Monografi }\end{array}$} & Tambah data monografi & Berhasil \\
\hline & Lihat data monografi & Berhasil \\
\hline & Delete data monografi & Berhasil \\
\hline & Edit data monografi & Berhasil \\
\hline \multirow{4}{*}{$\begin{array}{l}\text { Halaman Data } \\
\text { Kependudukan }\end{array}$} & Tambah data kependudukan & Berhasil \\
\hline & Lihat data kependudukan & Berhasil \\
\hline & Delete data kependudukan & Berhasil \\
\hline & Edit data kependudukan & Berhasil \\
\hline \multirow{4}{*}{$\begin{array}{l}\text { Halaman Data } \\
\text { penduduk }\end{array}$} & Tambah data penduduk & Berhasil \\
\hline & Lihat data penduduk & Berhasil \\
\hline & Delete data penduduk & Berhasil \\
\hline & Edit data penduduk & Berhasil \\
\hline \multirow{4}{*}{$\begin{array}{l}\text { Halaman data } \\
\text { pendidikan }\end{array}$} & Tambah data pendidikan & Berhasil \\
\hline & Lihat data pendidikan & Berhasil \\
\hline & Delete data pendidikan & Berhasil \\
\hline & Edit data pendidikan & Berhasil \\
\hline \multirow{4}{*}{$\begin{array}{l}\text { Halaman data } \\
\text { pekerjaan }\end{array}$} & Tambah data pekerjaan & Berhasil \\
\hline & Lihat data pekerjaan & Berhasil \\
\hline & Delete data pekerjaan & Berhasil \\
\hline & Edit data pekerjaan & Berhasil \\
\hline \multirow{4}{*}{$\begin{array}{l}\text { Halaman data } \\
\text { kendaraan }\end{array}$} & Tambah data kendaraan & Berhasil \\
\hline & Lihat data kendaraan & Berhasil \\
\hline & Delete data kendaraan & Berhasil \\
\hline & Edit data kendaraan & Berhasil \\
\hline
\end{tabular}


Vol. 3, No. 1, March 2021

p-ISSN: 2656-5935 http://journal-isi.org/index.php/isi e-ISSN: 2656-4882

\begin{tabular}{|l|l|c|}
\hline \multirow{4}{*}{$\begin{array}{l}\text { Halaman data } \\
\text { lapangan olah raga }\end{array}$} & Tambah data lapangan olah raga & Berhasil \\
\cline { 2 - 3 } & Lihat data lapangan olah raga & Berhasil \\
\cline { 2 - 3 } & Delete data lapangan olah raga & Berhasil \\
\cline { 2 - 3 } & Edit data lapangan olah raga & Berhasil \\
\hline \multirow{4}{*}{$\begin{array}{l}\text { Halaman data } \\
\text { tenaga medis }\end{array}$} & Tambah data tenaga medis & Berhasil \\
\cline { 2 - 3 } & $\begin{array}{l}\text { Lihat data tenaga } \\
\text { Medis }\end{array}$ & Berhasil \\
\cline { 2 - 3 } & Delete data tenaga medis & Berhasil \\
\cline { 2 - 3 } & $\begin{array}{l}\text { Edit data tenaga } \\
\text { Medis }\end{array}$ & Berhasil \\
\hline
\end{tabular}

\section{KESIMPULAN}

Dari paparan yang telah dikemukakan maka dapat disimpulkan beberapa hal sebagai berikut yaitu: (1) proses pengembangan sistem informasi eksekutif penduduk telah dikembangkan menggunakan waterfall model dengan lima tahapan yaitu communication, planning, modeling, construction, dan deployment. (2) sistem informasi yang dikembangkan memiliki fitur untuk melakukan pengelolaan data bagi admin dan laporan informasi keadaan penduduk bagi pihak eksekutif. (3) sistem informasi eksekutif dapat berjalan sesuai fungsinya yang dibuktikan dengan hasil pengujian menggunakan teknik black box.

\section{DAFTAR PUSTAKA}

[1] T. Hidayat and M. Muttaqin, "Pengujian sistem informasi pendaftaran dan pembayaran wisuda online menggunakan black box testing dengan metode equivalence partitioning dan boundary value analysis," Jutis Jurnal Tek. Inform., vol. 6, no. 1, pp. 25-29, 2020.

[2] U. Ependi, "Pengembangan E-Musrenbang Perencanaan Pembangunan Daerah (Studi Kasus: Kabupaten Ogan Komering Ulu)," in Seminar Nasional Informatika (SEMNASIF), 2015, vol. 1, no. 1.

[3] P. Sutopo, D. Cahyadi, and Z. Arifin, "Sistem Informasi Eksekutif Sebaran Penjualan Kendaraan Bermotor Roda 2 di Kalimantan Timur Berbasis Web," 2017.

[4] M. H. Prayitno, "Sistem Informasi Eksekutif Pemasaran Dengan Metode Drill Down,” J. Kaji. Ilm., vol. 17, no. 3, 2017.

[5] Y. Priyandari and U. S. Sundari, "Rancangan Informasi Eksekutif untuk Bidang Akademik dan Kemahasiswaan di Universitas Sebelas Maret," Performa Media Ilm. Tek. Ind., vol. 10, no. 2, 2011.

[6] E. W. Guntari, A. S. Permana, and F. R. Umbara, "Prototype Sistem 
Informasi Eksekutif Dosen di Perguruan Tinggi Swasta ABCD," JUMANJI (Jurnal Masy. Inform. Unjani), vol. 3, no. 02, pp. 53-61, 2020.

[7] E. Yulianingsih, N. Oktaviani, and U. Ependi, "Implementasi Simple Additive Weighting Penentuan Prioritas Penanganan Sumber Air Bersih," J. Sisfokom (Sistem Inf. dan Komputer), vol. 9, no. 1, pp. 77-82, 2020.

[8] B. Tujni and H. Hutrianto, "Pengembangan Perangkat Lunak Monitoring Wellies Dengan Metode Waterfall Model," J. Ilm. Matrik, vol. 22, no. 1, pp. 122-130, 2020.

[9] D. Komalasari and M. Ulfa, "Pengujian Usability Heuristic Terhadap Perangkat Lunak Pembelajaran Matematika," MATRIK J. Manajemen, Tek. Inform. dan Rekayasa Komput., vol. 19, no. 2, pp. 257-265, 2020.

[10] S. Suyanto and A. Andri, "Pengembangan Aplikasi Pencarian Klinik Dengan Algoritma Bellman Ford," Jusikom J. Sist. Komput. Musirawas, vol. 5, no. 1, pp. 70-81, 2020.

[11] U. Ependi, F. Panjaitan, and F. Syakti, "Pengembangan Aplikasi Mobile Travel Guide pada Provinsi Sumatera Selatan," J. Teknol. Inf. dan Ilmu Komput., vol. 7, no. 3, pp. 607-618, 2020.

[12] F. Fatmasari and S. Sauda, "Pemodelan Unified Modeling Language Sistem Informasi Enterprise Resource Planning," J. MEDLA Inform. BUDID ARMA, vol. 4, no. 2, pp. 429-436, 2020. 